\title{
シリカ充填ゴムのモデル化と変形挙動の評価*
}

\author{
望月利紀 ${ }^{* 1}$ ，北村真瑠久 ${ }^{* 2}$, 内藤正登 ${ }^{* 3}$ ，屋代如月 ${ }^{* 4}$ ，冨田佳宏 ${ }^{* 5}$
}

\section{Modeling and Evaluation of Deformation Behavior of Silica Filled Rubber}

\author{
Toshiki MOCHIZUKI ${ }^{* 1}$, Maruku KITAMURA, Masato NAITO, \\ Kisaragi YASHIRO and Yoshihiro TOMITA \\ *1 Graduate School of Engineering, Kobe University, \\ 1-1 Rokkodai, Nada-ku, Kobe-shi, Hyogo, 657-8501 Japan
}

\begin{abstract}
The rubbers containing various kinds of fillers exhibit fabulous mechanical characteristic and therefore, they are widely used in various production. Owing to the wide range of controllability in mechanical characteristics by adding the coupling agent, silica-filled rubber draws attention for extensive usage. Here, to clarify the mechanism of the marked increase in deformation resistance in silica-filled rubber in detail, we will construct the finite element homogenization models of silica-filled rubber. These models can reflect various experimental observations that include changes in microscopic structural characteristics such as distribution morphology of silica particles, the thickness of the interfacial phase between silica and rubber, and the networklike gel structures developed from the interfacial phase. The obtained results clarified the essential physical enhancement mechanisms of deformation resistance and hysteresis loss, i.e., the Mullins effect, for rubber filled with silica. The volume fraction of the silica coupling agent essentially affects the deformation behavior of silica-filled rubber suggesting the high controllability of the material characteristics of silica-filled rubber compared with carbon-black- filled rubber. Although, the present model underestimates the hysteresis loss as compared with the experimental results, it has a capability to evaluate the effect of adding coupling agents on the fundamental deformation behavior of silica filled rubber.
\end{abstract}

Key Words : Silica Filled Rubber, Visco Elasticity, Networklike Gel Structure, Interface, Finite Element Method

\section{1. 緒言}

ゴム材はカーボンブラックやシリカ等の各種マイクロ粒子を充填することにより弾性率の増加，引張強度，破 断エネルギーの増大等の機械的特性の向上がもたらされる. 加えて, 負荷時に比べ除荷時の応力が低下するヒス テリシス (履歴現象) や粘弾性的応答が未充填ゴムに比べて顕著になることが確認されている ${ }^{(1)}$.未充填ゴムの ヒステリシスや粘弾性挙動の発現については，分子鎖のからみ点数変化 ${ }^{(2)}$ や分子鎖の滑り ${ }^{(3)}$, 分子鎖の周囲の 分子鎖との相互作用 ${ }^{(4)}$ など様々なメカニズムが提案されてきた. 工業的な重要性から, マイクロ粒子充填ゴムの 変形挙動についての研究は多く(3) (6), 現象論的な構成式を用いて変形応答を再現する研究(3),(5),(6) とマイクロ粒子を 含有したゴムユニットセルを用いた研究(2)(7)(8)に分類できる. 後者によって, 充填に伴うゴム部の不均一変形とそ の伝播挙動が高機能性発現をもたらす主要なメカニズムであることがはじめて明らかにされ(2)(7)(8), マイクロ粒子 の形状，体積含有率，分布形態等とマイクロ粒子充填ゴムの変形特性を直接関係つけることを可能とした. その 後, 関連の研究が鋭意推進され, カーボンブラック(CB)充填ゴムに関して得られた研究成果は実際のタイヤの設 計にも用いられている(9)(10).

現在，工業的に利用されているゴム材の多くは CB が充填材として用いられているが，CB に代わる充填材と してシリカが注目されている. タイヤの場合，シリカ充填ゴムは，CB 充填ゴムに較ベタイヤの転がり抵抗が小 さくなるため燃費が向上すること ${ }^{(11)}$ ，ならびに石油を資源としないシリカは，脱石油にも貢献すること等の長

\footnotetext{
* 原稿受付 2010 年 7 月 9 日

*1 学生員, 神戸大学大学院工学研究科

*2 (株) デンソー（テ448-8661 愛知県刈谷市昭和町 1-1）

*3 正員，住友ゴム工業 (株)（干651-0071 兵庫県神戸市中央区筒井町 2-1-1）

*4 正員, 神戸大学大学院工学研究科（干657-8501 兵庫県神戸市灘区六甲台町 1-1）

*5 正員, フェロー, 福井工業大学工学部（†910-8505 福井県福井市学園 3-6-1）

E-mail: mochizuki@mail.mm4.scitec.kobe-u.ac.jp
} 
所があげられる，さらに，シリカ充填ゴムにおいては，界面結合剤（カップリング阂）の添加によりシリカとゴム の界面の結合状態を制御し, シリカ充填ゴムの力学特性を大幅に変化させることが可能である. しかしながら, カッ プリング剂の一部はゴム相の分子鎖と分子鎖を結合させる架橋剂の役割をすることが示唆されており ${ }^{(12)}$ ，カッ プリング剂の添加によってシリカ充填ゴムに大幅な力学的特性の変化をもたらすメカニズムに関して未知な点が 多い. シリカ充填ゴムの特性を生かした使途の一層の拡大を図るためには，さらなる研究が必要である.

そこで本研究では, カップリング剤添加によるシリカ界面ゴム相ならびに近傍のゴム相のからみ点変化がもた らすシリカ充填ゴムの特性変化のメカニズムを明らかにすることを目的として新たに提案した様々なモデルを用 いたシミュレーションを行い，シミュレーション結果と実験結果を比較することにより，カップリング剂添加が シリカ充填ゴムの特性変化に与える影響を適切に評価可能なモデルを提示する.

\section{2. 構 成 式}

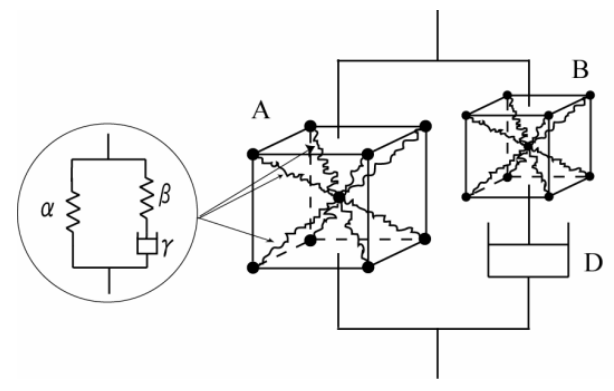

Fig. 1 Revised eight chain model.

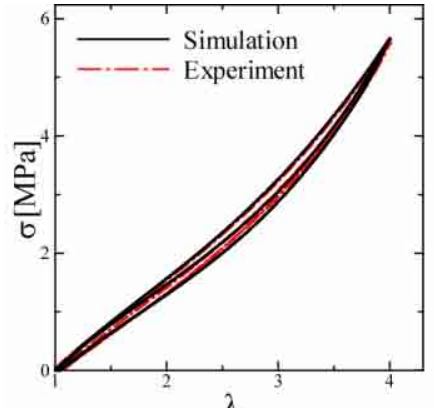

(a)

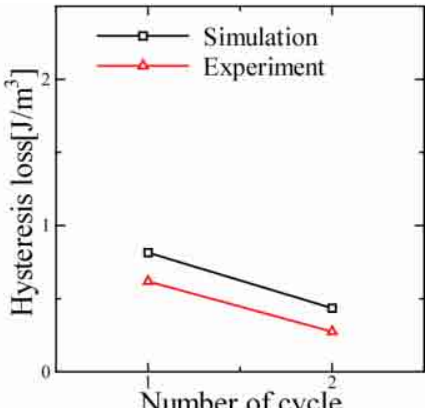

(b)

Fig. 2 Comparison of simulation and experiment.

(a)True stress-stretch relations, (b)Hysteresisloss.

本研究ではゴムの粘弾性挙動を記述するために, 冨田らが提案した粘弾性 8 鎖モデル (2) と, 粘性抵抗を表すダ ンパーを図 1 のように導入した粘弾性モデルを用いる. 8 鎖モデル A の主ストレッチ方向の応力 $\sigma_{\mathrm{A} i}$ とストレッチ $\lambda_{i}$ は次式で関係付けられる.

$$
\sigma_{\mathrm{A} i}=\frac{1}{3}\left\{C_{\alpha}^{R} \sqrt{N_{\alpha}} \mathcal{L}^{-1}\left(\frac{\lambda_{c}}{\sqrt{N_{\alpha}}}\right)+C_{\beta}^{R} \sqrt{N_{\beta}} \frac{1}{\lambda_{\gamma}} \mathcal{L}^{-1}\left(\frac{\lambda_{\beta}}{\sqrt{N_{\beta}}}\right)\right\} \frac{\lambda_{i}^{2}}{\lambda_{c}}
$$

さらに, 図 1 の 8 鎖モデル B の主ストレッチ方向の応力 $\sigma_{\mathrm{B} i}$ とストレッチ $\lambda^{\prime}{ }_{i}$ は次のように表せる.

$$
\sigma_{B i}=\frac{1}{3}\left\{C_{B}^{R} \sqrt{N_{B}} \mathcal{L}^{-1}\left(\frac{\lambda_{c B}}{\sqrt{N_{B}}}\right)\right\} \frac{\lambda_{i}^{\prime}}{\lambda_{c B}}
$$

ここで $C_{\alpha}^{R}=n_{\alpha} k_{B} T, C_{\beta}^{R}=n_{\beta} k_{B} T, C_{B}^{R}=n_{B} k_{B} T, n=n_{\alpha}+n_{\beta}+n_{B}$ は単位体積中に含まれる鎖の数, $N_{\alpha}, N_{\beta}, N_{B}$ は 1分子鎖あたりのセグメント数で, $\sqrt{N_{\alpha}}, \sqrt{N_{\beta}}, \sqrt{N_{B}}$ は分子鎖の限界伸びを表す.また, 図1に示す 8 鎖モデ ル A の単分子鎖の各要素のストレッチを $\lambda_{\alpha}, \lambda_{\beta}, \lambda_{\gamma}, 8$ 鎖モデル $\mathrm{B}$ のストレチを $\lambda_{c B}$, ダンパーDのストレッ チを $\lambda_{D}$ とする. このとき, $\lambda_{\alpha}=\lambda_{c}=\lambda_{\beta} \lambda_{\gamma}=\lambda_{c B} \lambda_{D}$ である. $\quad \mathcal{L}^{-1}$ は Langevin 関数の逆関数を表す. これらの応 力を加え合わせることにより主応力 $\sigma_{i}$ と主ストレッチ $\lambda_{i}$ の関係を得る.

上記の構成式(1), (2)はからみ点数が変化しないと仮定したアフィンモデルによる構成式であるが, それで説明 できない繰り返し変形時の応力軟化に伴うヒステリシスロスの発現などの実験的事実 ${ }^{(1)}$ を考慮して, からみ点数 が変化することを許容する非アフィン分子鎖網目モデル (13) を用いて構成式(1), (2)を一般化する. 網目構造の変 化によりからみ点数が減少し, 式(1), (2)の 1 分子鎖あたりの平均セグメント数 $N$ は増加する. その結果, 単位体 積中の分子鎖 $n$ は減少し, 伸長可能性の向上と岡性の低下をもたらす. 本研究では, $N$ が $\lambda_{c}$ に依存すると仮定して, 


$$
N\left(\lambda_{c}\right)=N_{0}+f\left(\lambda_{c}\right)
$$

とする. ここで, $N_{0}$ は初期セグメント数, $f\left(\lambda_{c}\right)$ は $\lambda_{c}$ の 2 次多項式で表すことにする. なお，からみ点数の変化式(3)は 8 鎖 モデル A 内の要素 $\alpha$ のみに適用し, 要素 $\beta$ や 8 鎖モデル $\mathrm{B}$ のからみ点数は変化しないものとした.

図 2(a)の 1 点差線で示寸繰り返し負荷を与えたときの未充填ゴムの実験結果を再現するため, 以下のようにし て式(1)から(3)の具体形を決めた．まず第 1 回目のサイクルでは，負荷時のからみ点数が変化し，除荷時はそれが 変化しないとして, 式(1)から(3)を用いたシミュレーション結果と実験結果の差が最小となるように, 各材料定数 を同定する. 本シミュレーションでは, 一旦除荷した後, 再負荷時において前回のサイクルで到達した最大スト レッチより小さい領域では, からみ点数の変化は不可逆なものとし, 平均セグメント数 $N$ は変化しないものとし た. 寸なわち 1 回目のサイクルの除荷と 2 回目のサイクルの再負荷の $N$ の值は同一とした. このようにして非ア フィン分子鎖網目モデルへ一般化した式(1)から(3)により予測した未充填ゴムの繰り返し変形応答を図 2(a)の実 線にて示す。図 2(b)に各サイクルのヒステリシスロスの関係を示す，ヒステリシスロスは負荷時と除荷時の応力 一ストレチ曲線で囲まれた部分の面積で評価している. 図 2 より，提案した構成式によって実験において見ら れる繰り返し負荷を受ける未充填ゴムの変形挙動の特徵を良好に再現できることがわかる. 以下の解析において は，このようにして得られた未充填ゴムの構成式をシリカ充填ゴムのゴム部の構成式として用いる.

\section{3. シリカ粒子界面近傍の特性変化が変形挙動に及ぼす影響}

本章では，カップリング剤を用いることによりもたらされるシリカ粒子界面ゴム相の材料特性の変化が変形挙動 に及ぼす影響について検討する．シリカ充填ゴムにおいては，ゴムの製造過程でカップリング剂を用いることに より，シリカ粒子とゴムを化学的に結合させ，シリカ粒子界面とゴム相の間の結合力を制御できることが知られ ている.このためシリカ界面のゴム相は，からみ点数が増えることで他のゴム部に較べ一分子鎖あたりのセグメ ント数が少なくなっていることが示唆されており，その程度はカップリング剤の含有量に依存寸る．しかしなが ら, カップリング剂添加によるゴム相の変質や形態について未知な部分が多く, 界面近傍の特性変化は顕著であ ることが知られているものの，定量的に添加剤と界面相の厚さとの関係を提示するに至っていなかった．そのた めに，何らかの基準となる界面相の厚さの設定が必要となった．そこで，熱重量測定により求めたゲルの重量か ら, 界面相の厚さはシリカ粒子径に対し $20 \%$ 程度の体積に等価であると判断した ${ }^{(14)}$.このようにして, 本論文で は粒子径の 20\%の界面ゴム相の厚さを基準として, 界面ゴム相の特性あるいは厚さをパラメトリクに変化させ, それがシリカ充填ゴムの特性に及ぼす影響をシミュレーションによって評価することによって，モデルの適切性 を検討する。

\section{$3 \cdot 1$ 界面からみ点変化モデルによる検討}

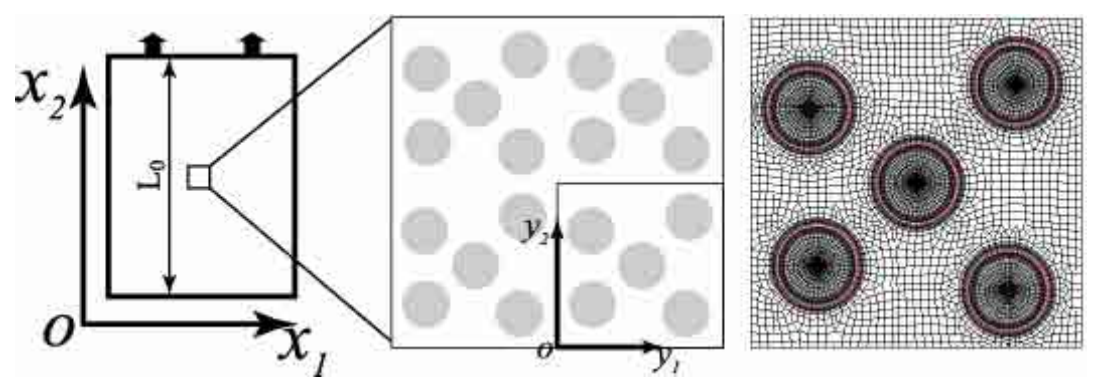

Fig. 3 Simulation model of Silica filled rubber.

図 3 にシリカ粒子含有率 $f_{0}=20 \%$ のリカ充填ゴムの解析モデルを示寸. 本研究では, 周期的微視構造を有する材料全体 を表現する座標系 $x_{i}$ と微視構造を表現する座標系 $y_{i}$ の 2 変数を用い, 変位を漸近展開して表示した均質化理論に基づき定式 化した有限要素法(14)(15)を用いる. 本研究で直接用いる粘弾塑性均質化理論並びに有限要素程式の具体形及び計算手順の詳 
細については文献(15), (16) を参照されたい. シリカ充填ゴムを図3に示寸ような粒子径が全て等しい平面ひずみモデルで 近似し，巨視的モデルの上端面に $x_{2}$ 方向に変位速度 $\dot{u}=100[\mathrm{~mm} / \mathrm{min}]$ を与様変形を発生させた. 右端のユニットセルモ

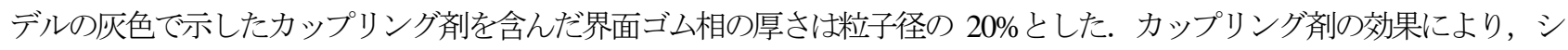
リカとゴムが化学的に結合し，このような領域においてゴム相は一分子鎖あたりのセグメント数が少なくなっていることが 示唆される. そこで, 界面近傍のゴム相のカップリング剤の効果を検討するために, シリカとゴム相の界面は完全固着とし, 界面ゴム相の要素 $\alpha$ のグメント数 $N_{\alpha}^{s}$ の值を $N_{\alpha}^{s}=1.2,2.0,4.0,10.0$ と変化させて解析を行った. 一方, 界面相以外の ゴム相の応答については， $N_{\alpha 0}=12.5$ の非アフィン分子鎖網目理論を用いて表示した. 粒子の岡性は，ゴム材の岡性に比 ベて十分大きいと考え, 計算の安定性と結果にほとんど影響を与えない值として, 縦弾性係数 $E=100[\mathrm{MPa}$, ポアソン比 $v$ $=0.3$ とした. 材料の温度は変形過程を通して一定で, $T=296[\mathrm{~K}]$ とした.

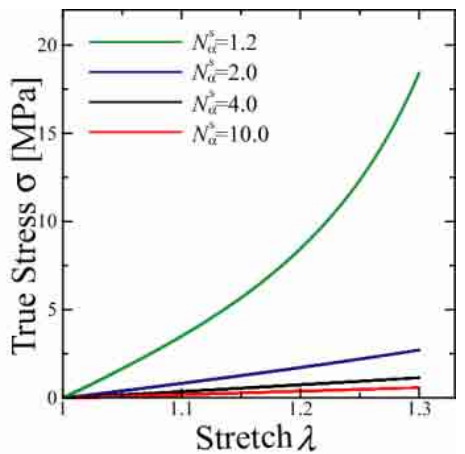

Fig. 4 True stress-stretch relations of interface rubber.

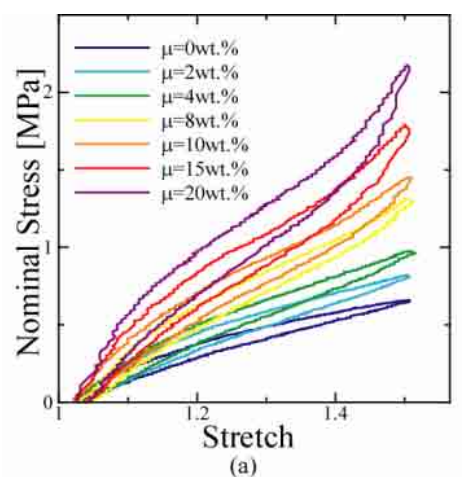

Fig. 5 Comparison of nominal stress-stretch relations by

図 4 に界面ゴム単相の真応力 - ストレッチ関係を, 図 5(a)にシリカ粒子含有率 20\%のゴム材にカップリング剤 の重量\%(以降含有率)を変化させた場合の実験結果，(b)に界面ゴム相のからみ点数を変化させたときのユニット セル全体の応答を示す．実験では 1 サイクル目に材料の内部構造が成型後の初期状態から緩和した安定構造に変 化するので，1 サイクル目と 2 サイクル目以降の特性は大きく異なる ${ }^{(17)}$. 通常は定常化した状態における材料の 挙動を扱うので，実験の結果は後続の繰り返しとほぼ等しい2 2 サイクル目を取り上げた，一方シミュレーション では，成形後の安定した状態における実験結果から構成式の材料パラメータの同定を行っているので，1サイク ル目と 2 サイクル目では, 大きな差は見られなかったために, 1 サイクル目の応答を示して比較することとした. 図 4 に示すように，界面ゴム相の一分子鎖あたりのセグメント数を小さくすることで界面ゴム単相の変形抵抗は 大きく変化しているものの, 図 5(b)に示す, ユニットセル全体の変形抵抗の上昇は小さく, 図 5(a)に示すような カップリング剤含有率を大きくしたときの実験結果に見られるような著しい変形抵抗の増大を再現できていない ことがわかる．これは，本モデルにおける界面ゴム相の他のゴム部に占める割合が小さいために，その部分のか らみ点の変化は巨視的な応答の変化に大きくは影響を与えないことによる. この結果から, 界面領域のからみ点 の制御のみでは，実験結果に見られるカップリング剤含有量の増加に伴う変形抵抗の増大を表現できないことが 明らかとなった。

\section{$3 \cdot 2$ 界面厚さ変化モデルによる検討}

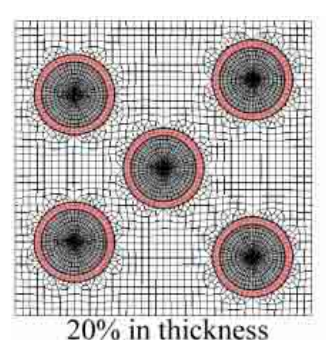

$20 \%$ in thickness

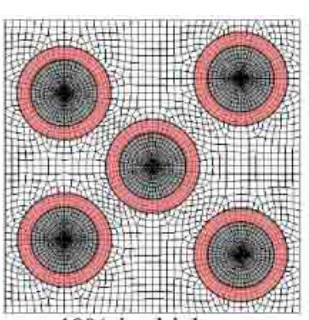

$40 \%$ in thickness

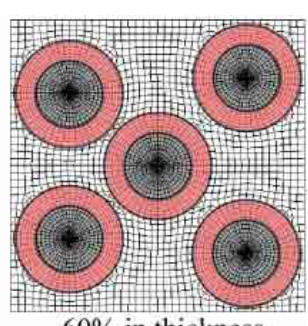

$60 \%$ in thickness

Fig. 6 Computational models with different thickness of interface between silica and rubber 
実験的な観測は，カップリング剤の添加量の増加は，カップリング剤の影響範囲の拡大をもたらすことを示唆し ている ${ }^{(14)}$ ，そこで本節では，図 6 に示すように，カップリング剤の含有量に比例して，界面ゴム相の体積が変化 し，それに伴って厚さも変化すると仮定し，界面厚さが変形挙動に及ぼす影響を検討する．前節同様，シリカ粒

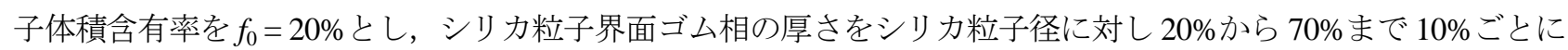
変化させて解析を行った. ここで界面ゴム相のからみ点数は, 他のゴム部に較べ十分大きいものと仮定し, 要素

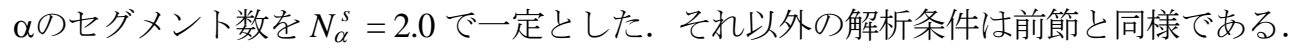

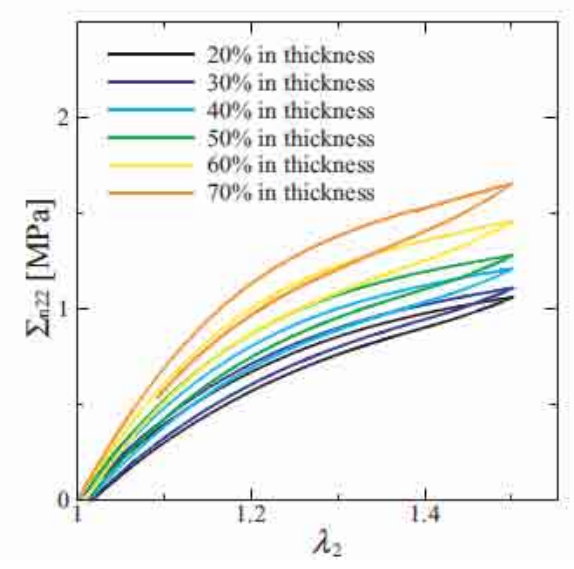

Fig. 7 Nominal stress-stretch relations by simulation.
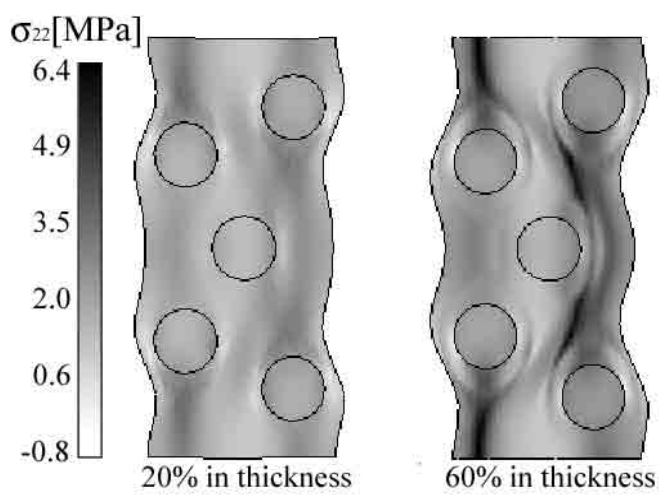

(a)
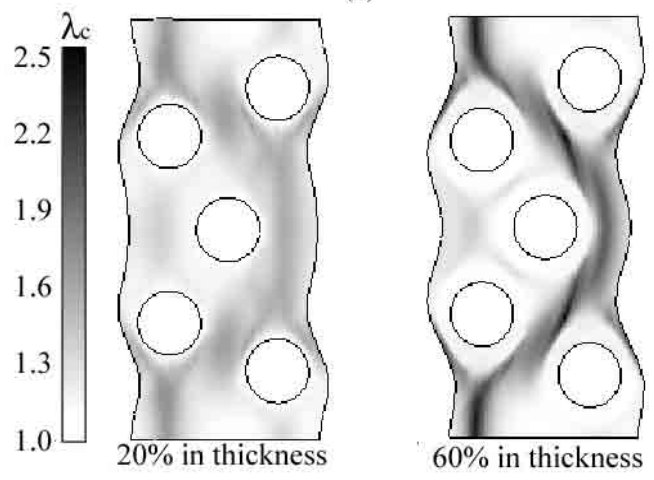

(b)

Fig. 8 Distribution of (a)tensile stress $\sigma_{22}$,

(b)molecular chain stretch $\lambda_{\text {c }}$.

図 7 にシリカ含有率 20\%の場合に対して, シリカ粒子界面ゴム相の厚さを変化させたときの解析結果を示す. 図 5(a)に示すカップリング剤の含有率増加に伴う比較的変形が小さい領域の忘力の上昇傾向を再現できているこ とがわかる.この要因を詳細に検証するために, ユニットセル内の応力および分子鎖ストレッチの分布を調べた. 図 8 に界面ゴム相の厚さがシリカ粒子径に比して $20 \%, 60 \%$ の場合の $\lambda_{2}=1.5$ における(a)引張方向の応力 $\sigma_{22}$ 分布, (b)分子鎖ストレッチ $\lambda_{\mathrm{c}}$ の分布を示寸. 図 8(b)の分子鎖ストレッチ分布が示すように，シリカ粒子界面ゴム相は他 のゴム部に較べからみ点数を大きくしたため, 変形抵抗が大きく, 変形し難い領域となっていることが分かる. このように, 界面ゴム相の厚さを大きくすると変形し難い領域が大きくなり, 見かけ上のシリカ粒子含有率が増 加し，変形を担うゴム相が相対的に小さくなり，粒子連結部において著しい変形の集中をもたらし，より顕著な 分子鎖の配向硬化を促す，その結果，図 8(a)に示寸ような局所的な領域で応力が集中し，ユニットセル全体の変 形抵抗の上昇をもたらす.

このように，シリカ粒子界面ゴム相の厚さを大きくすることで実験結果に見られるカップリング剤増加に伴う 変形抵抗の増加を再現できることを確認できた。 しかしながら, 極端に厚い界面相が必要な上に変形が大きいと ころでの立ち上がりの再現性がよくない，従って，シリカ充填ゴムにおけるカップリング剤の影響は，シリカ粒 子界面ゴム相の厚さのみに限定されるものではないと考えられる. 


\section{4. ゲルネットワークの特性変化が変形挙動に及ぼす影響}

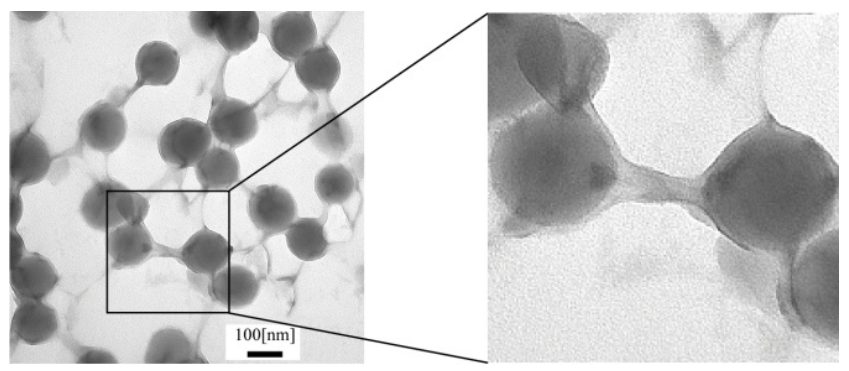

Fig. 9 Network structure of silica filled rubber by TEM ${ }^{(17)}$.

シリカ充填ゴムにおけるカップリング斉充填効果の影響に関する最近の実験的な検討結果 ${ }^{(18)}$ によると, 図 9 の TEM 画像が示すように, シリカ粒子間のゴム相に界面相の一部が成長し，ゲルネットワーク状の構造(ネットワ 一ク構造)を形成していることが示唆される，そこで本章では, そのような実験事実を反映するため, 粒子同士 がゲルネットワークによって連結したシリカ充填ゴムのモデルを構築し，ゲルネットワーク構造ならびにゲル相 のからみ点の変化が巨視的な応答に及ぼす影響を検討する.

\section{$4 \cdot 1$ ゲルネットワーク構造が変形挙動に与える影響}

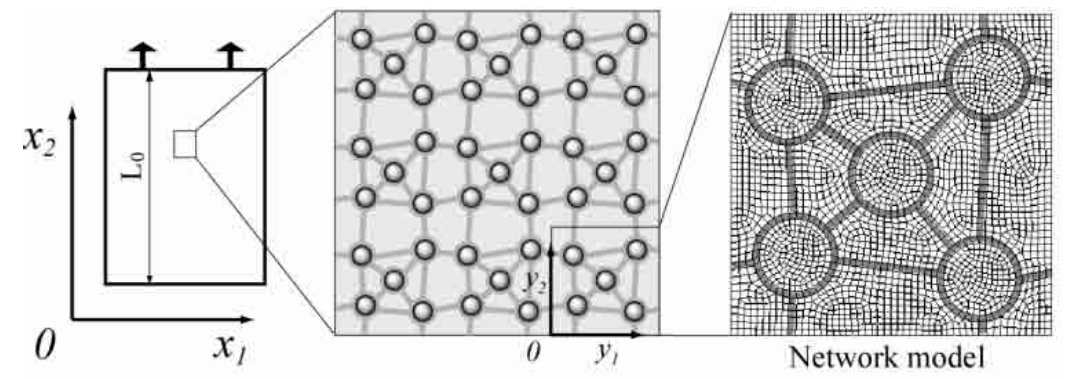

Fig.10 Computational model of silica filled rubber with networklike gel phase.

本節では，図 9 に示すシリカ充填ゴムに見られるゲルネットワーク構造がシリカ充填ゴムの力学特性に及ぼす影 響を検討するため, 図 10 に示すような含有率 $f_{0}=20 \%$ のシリカ粒子間で界面組織がネットワーク構造を形成した ネットワークモデルを構築した。 ここで，灰色で示した界面・ネットワークゲル相の面積は，図 3 に示すモデル と等しくした。さらにシリカ界面ゴム相及びネットワーク相はカップリング剂の作用により分子鎖のからみ点数 は著しく多くなっていることが示唆されるので, 本モデルでは界面・ゲルネットワーク相のセグメント数を $N_{\alpha}^{s}=$ 2.4 とした. この部分以外のゴム相のセグメント数, その他の各材料定数は未充填ゴムと同様とした.

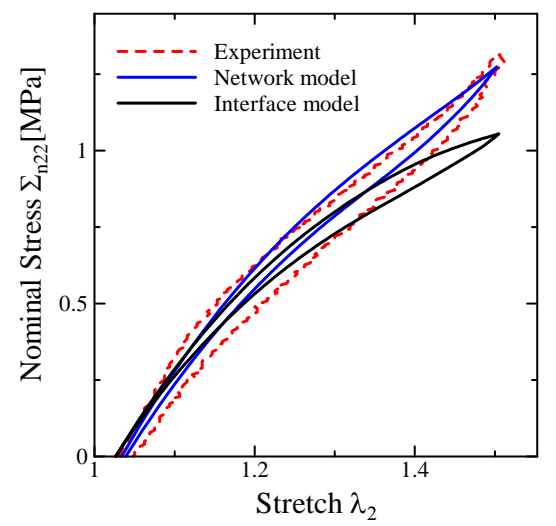

Fig.11 Comparison of nominal stress-stretch relations. 
図 11 にネットワークモデル，界面モデルの応カーストレッチ関係を示す．これよりネットワークモデルでは,界面モデ ルに比べ, 変形後期に変形抵抗が増大し，実験結果に見られる応力の立ち上がりを良好に再現していることがわかる.これ は, 変形の進行に伴って, 連結した平均セグメント数が少ないゲル相に著しい配向硬化が進行し, 変形抵抗の増大をもたら した結果であると考えられる。

\section{$4 \cdot 2$ ゲル相からみ点数の変化が変形挙動に与える影響}

界面・ゲルネットワーク相では, 実験によりカップリング剤由来の硫黄が検出されていることからカップリング剤が存在 していることが示唆されている. そのためこのような領域ではゴム分子鎖が相互に化学的に結合し，からみ点数が増加する ことで,一分子鎖あたりのセグメント数が少なくなっており,その程度はカップリング剤の含有率に依存すると考えられる. そこで本節では，カップリング風含有率の変化に伴い界面・ゲルネットワーク相のからみ点が変化し，一分子鎖あたりのセ グメント数が変化した場合について検討した. 解析モデルは図 10 に示したネットワークモデルを用い, 界面・ゲルネット ワーク相の要素のセグメント数 $N_{\alpha}^{s}$ の值を 2.6, 3.0, 4.0, 5.0 と変化させた. それ以外の解析条件についてはこれまでと同 様とした.

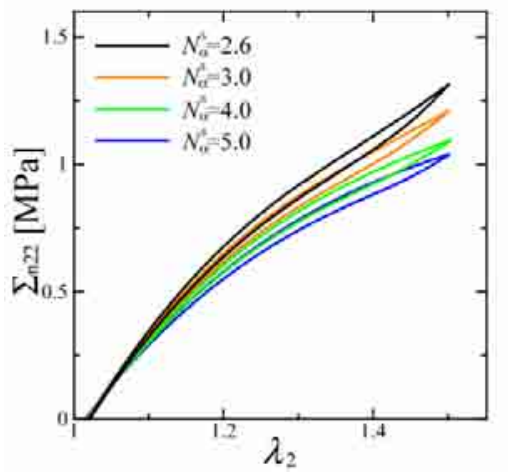

Fig. 12 Computationally evaluated nominal stress-stretch relations

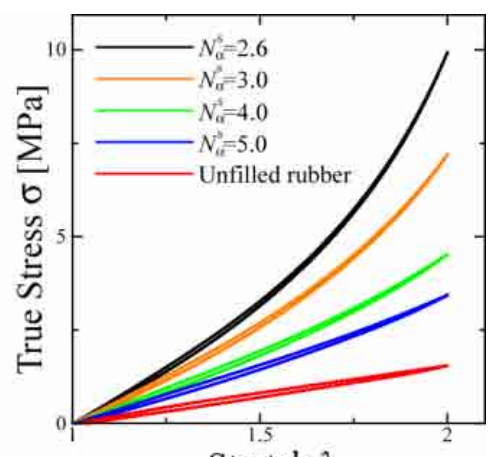

Stretch $\lambda$

Fig. 13 True stress stretch relations of interface, and unfilled rubber.
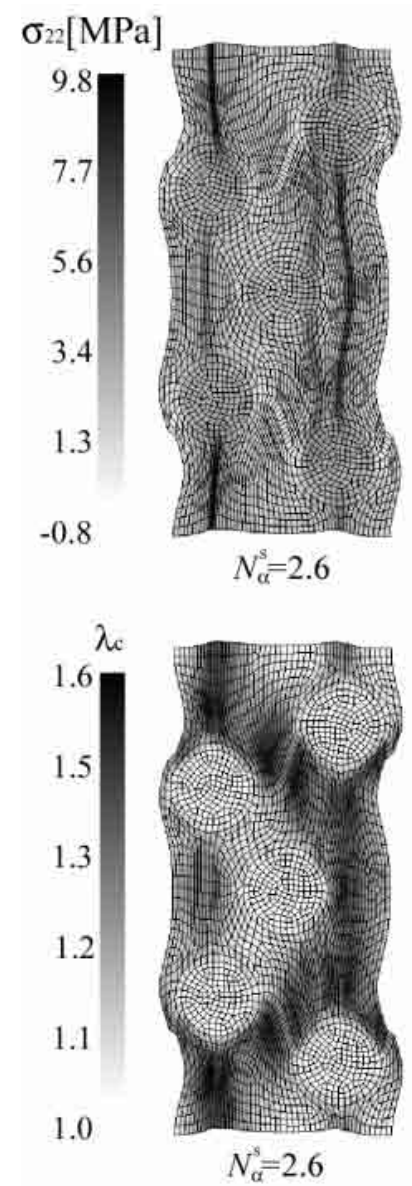

(a)
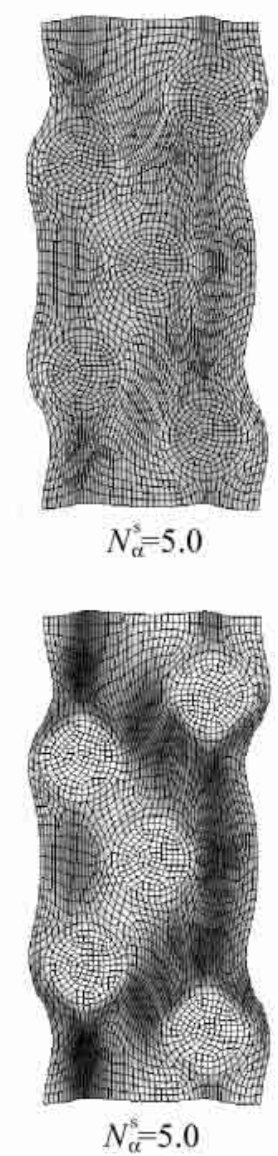

(b)

Fig. 14 Distribution of (a)tensile stress $\sigma_{22}$,

(b)molecular chain network stretch $\lambda_{\text {c. }}$.

図 12 にシリカ粒子含有率 $20 \%$ の場合のゲル相のからみ点数を変化させたときの公称応力とストレッチの関係の解析結果 を示寸．これより，ゲル相のからみ点数の増加に伴ってもたらされるセグメント数 $N_{\alpha}^{s}$ の減少によって，図5(a)の実験結果 に見られるカップリング猟増加に伴う応力の上昇傾向を再現できていることがわかる.

これら解析結果に見られるような界面・ゲルネットワーク相のからみ点数の増加による応力上昇の要因を詳細に検討寸る ために，ゲル単相の変形挙動とユニットセル内の応力と分子鎖ストレッチの分布を検討した. 図 13 に通常の未充填ゴムと 
ゲル単相の真応力ーストレッチ関係を, 図 14 に $N_{\alpha}^{s}=2.6,5.0$ とした場合の $\lambda_{2}=1.5$ における(a)引張方向の応力 $\sigma_{22}$ 分布, (b)分子鎖ストレッチ $\lambda_{c}$ 分布を示寸. 図 14 (b)の分子鎖ストレッチ分布から，界面・ゲルネットワーク相はその他のゴムに較 ベカップリング剤の効果によりからみ点数を多くしたため, 変形後期では配向に伴い限界ストレッチに近付き, 変形抵抗の 大きなゴムとなり周囲のゴムに較べ変形の進行が抑制される. 特にネットワーク部近傍では, その領域の変形を補うように 周囲のゴムが大きく伸びていることがわかる. 伸長方向に並んだネットワーク部において分子鎖の配向硬化が進行すること により，変形抵抗の著しい増加がもたらされ，図 14(a)の応力分布に見られる極度な応力集中が生じている. その結果，ユ ニットセル全体の変形抵抗が上昇したと考えられる. 界面・ゲルネットワーク相のからみ点数が大きくなるほど, この傾向 は顕著になっている.

以上の結果は, 粒子間を連結する領域における変形の集中がもたらす高ストレッチに誘引される配向硬化に加えて, 界 面・ゲルネットワーク相の材料特性の変化が変形挙動に一層大きな影響を与えていることを示唆している. 前者は, すでに 明らかにしているCB 充填ゴムの強化メカニズム(2)(7)(10)に対応し, 後者は, シリカ充填ゴムに特有の強化メカニズムである. このように提案したモデルによって, シリカ充填ゴムの変形応答の特性を適切に表現できているものと考えるが, 一方ヒス テリシスロスに関しては, シミュレーション結果は実験結果に較べて小さくなっている. 後者の要因に関しては今後の検討 課題である.

\section{5. 結 言}

カップリング剤の添加によりカ学特性を広範囲に制御可能なシリカ充填ゴムの力学特性の評価を目的と して, シリカ粒子とゴムとの界面ならびにその影響領域の特性がシリカ充填ゴムの応答に及ぼす影響を評価 可能なモデルを有限要素均質化法を用いて構築し，シミュレーションによって得られた知見を示す.

（1）界面ゴム相のからみ点数を増加させた場合, 全体的な変形抵抗がわずかに上昇したものの, 実験結果に見 られるようなカップリング剤増加に伴う著しい変形抵抗の増大は再現できないことが確認された.

(2) 界面相を厚くすると不変形領域が大きくなり, 変形を担う限られた領域において顕著な変形の集中が生じ 配向効果がもたらされ，実駼結果に見られる変形抵抗の増大を再現できることを確認した。 しかしなが ら，界面相の厚さは現実のものとは大きく異なることが分かった.

（3）界面相が成長してネットワーク構造を形成することを示唆している最近の TEMによる実験結果を反映し たネットワークモデルを構築した，これによって，ネットワーク相の配向硬化が進行し変形抵抗が増大 することにより，実験結果に見られる変形後期の変形抵抗の上昇を良好に再現可能なことがわかった.

（4）カップリング剂増加に伴い, 界面・ネットワーク相のからみ点数が増加し, 周囲のゴムに比べ変形抵抗の 増加をもたらす. その結果, 伸長方向に並んだネットワーク部において分子鎖の配向硬化が進行し著し い応力集中が発生し, 実験に見られるカップリング剂増加に伴う変形抵抗の上昇傾向や，高ストレッチ 時の変形抵抗の立ち上がりを再現できていることがわかった. しかしながら, ヒステリシスロスの過少 評価についてさらなる検討が必要である.

（5）図及び表の横に空白ができても，その空白部には本文を記入してはならない.

（6）図及び表は，余白部分にはみ出してはならない.

最後に, 本研究の一部は科学研究費の補助の下において推進された. 実験データを提供して頂いた住友ゴム工業（株）と ともに記して謝意を表する.

\section{文献}

(1) Mullins, L., Thixotropic Behavior of Carbon Black in Rubber, Rubber Chemistry and Technology, Vol. 23, (1948), pp. 281-300.

(2) 古谷泰大, 内藤正登, 陸偉, 冨田佳宏, カーボンブラック充填ゴムの繰り返し変形挙動の評価, 日本機械学会 論文集 A 編, Vol. 71, No. 4, 708(2005), pp. 1109-1115. 
(3) Dannenberg, E. M., The Effects of Surface Chemical Interactions on the Properties of Filler - Reinforced Rubbers, Rubber Chemistry and Technology, Vol. 48, (1975), pp. 410-444.

(4) 深堀美英, 設計のための高分子の力学, (2000), 技報堂出版.

(5) Bergstöm, J. S. and Boyce, M. C., Constitutive Modeling of the Large Strain Time-Dependent Behavior of Elastomers, Journal of Mechanical Physics and Solids, Vol. 46, No. 5(1998), pp. 931-954.

(6) O’Brien, J. et al., An NMR Investigation of the Interaction between Carbon Black and cis-Polybutadiene, Macromolecules Vol. 9, No. 4 (1976), pp. 653-660.

(7) Tomita, Y., Lu, W. and Furutani, Y., Micro- to Macroscopic Deformation Behavior of Carbon Black-Filled Rubber Under Monotonic and Cyclic Straining, Proc. CIMTEC2004,PartB, (2004), pp. 121-132.

(8) Tomita, Y., Azuma, K., and Naito, M., Strain - Rate - Dependent Deformation Behavior of Carbon Black - Filled Rubber Under Monotonic and Cyclic Straining, Key Engineering Materials, Vol. 340, No. 341(2007), pp. 1017-1024.

(9) 内藤正登, 東圭佑, 馬㴊貴裕, 村岡清繁, 冨田佳宏, カーボンブラック充填ゴムの内部構造が変形挙動に及ぼす影 響, 日本機械学会論文集 A 編, Vol. 73, No. 734(2007), pp. 1120-1127.

(10) Y. Tomita, K. Azuma , M. Naito, Strain - Rate - Dependent Deformation Behavior of Carbon - Black - Filled Rubber under Monotonic and Cyclic Straining, Int. J. Mech. Sci. 50-5 (2008) 856-868.

(11) Wolff, S., Silanes in Tire Coupling After Ten Years - A Review, Tire Society and Technology, Vol. 15, No. 4(1987), pp. 276-294.

(12) 松沢憲治, シリカハランフィラーシステムの化学とゴム補強性, 日本ゴム協会誌,Vol. 78, No. 6(2005), pp. $211-217$.

(13) Tomita, Y., Adachi, T. and Tanaka, S., Modeling and Application of Constitutive Equation for Glassy Polymer Based on Nonaffine Network Theory, European Journal of Mechanics, A/Solids, Vol. 16, No. 5(1997), pp. 745-755.

(14) 住友ゴム工業株式会社, 内部資料

(15) Higa, Y. and Tomita, Y., Computational Prediction of Mechanical Properties of Nickel - based Superalloy with Gamma Prime Phase Precipitates, Proceedings of ICM8, Advance Materials and Modeling of Mechanical Behavior, Vol.III, (1999), pp. 1061-1066.

(16) 比嘉吉一, 冨田佳宏, 粒子強化型複合材の均質化法による変形挙動のモデル化とシミュレーション, 日本機械 学会論文集 A 編, Vol. 66, No. 648(2000), pp. 1441-1446.

(17) Jean-Baptiste. D., Emmanuel. C., Reinforcement of Elastomers by Particulate Fillers, The Science and Technology of Rubber Third Edition, (2005) pp. 367-400.

(18) 住友ゴム工業株式会社提供 TEM 画像 